\title{
Barriers and drivers towards the incorporation of crop residue in the soil. Analysis of Italian farmers' opinion with the theory of planned behaviour
}

\author{
Luca Bechini, ${ }^{1}$ Chiara Costamagna, ${ }^{2}$ Laura Zavattaro,, Carlo Grignani, ${ }^{2}$ Jo Bijttebier, ${ }^{3}$ \\ Greet Ruysschaert ${ }^{4}$ \\ ${ }^{1}$ Department of Agricultural and Environmental Sciences-Production, Landscape, Agroenergy, \\ University of Milano, Milano, Italy; ${ }^{2}$ Department of Agricultural Forest and Food Sciences, \\ University of Torino, Grugliasco (TO), Italy; ${ }^{3}$ Institute for Agricultural and Fisheries Research, \\ Social Sciences Unit, Merelbeke, Belgium; ${ }^{4}$ Institute for Agricultural and Fisheries Research, Plant \\ Sciences Unit, Merelbeke, Belgium
}

\begin{abstract}
Despite the benefits arising from incorporating crop residue in the soil, some farmers decide to burn or sell it. The objective of the work described in this paper was to quantify the adoption of crop residue incorporation by Italian farmers, and to identify the barriers and drivers that they perceive towards this agricultural management practice.
\end{abstract}

Correspondence: Luca Bechini, Department of Agricultural and Environmental Sciences-Production, Landscape, Agroenergy, University of Milano, via Celoria 2, 20133 Milano, Italy.

E-mail: luca.bechini@unimi.it

Key words: Control factors; intention; outcomes; referents; residue decomposition; soil fertility.

Acknowledgments: this work is part of a larger survey conducted in eight European countries within the FP7 project CATCH-C. The project CATCH-C (Grant Agreement $\mathrm{N}^{\circ}$ 289782) is co-funded by the European Commission, Directorate General for Research \& Innovation, within the 7th Framework Programme of RTD, Theme 2 - Biotechnologies, Agriculture \& Food. The views and opinions expressed in this article are purely those of the writers and may not in any circumstances be regarded as stating an official position of the European Commission. This work would not have been possible without the help of hundreds of farmers and of many colleagues who helped to get in touch with them: Universities of Ancona, Bari, Milano, Napoli Udine, Pisa, Teramo, Tuscia, Ancona and Perugia; provincial and regional officials; farmers unions (Coldiretti, Confagricoltura, Confederazione Italiana Agricoltori); CadirLab (Quargnento, AL); Consorzio Agrario di Siena; advisors of the Italian Farm Accountancy Data Network (RICA); students of the University of Torino and University of Milano.

Conference presentation: SIA XLIII Congress, Pisa, 2014.

Received for publication: 8 February 2015.

Revision received: 20 July 2015.

Accepted for publication: 7 August 2015.

(C) Copyright L. Bechini et al., 2015

Licensee PAGEPress, Italy

Italian Journal of Agronomy 2015; 10:663

doi:10.4081/ija.2015.663

This article is distributed under the terms of the Creative Commons Attribution Noncommercial License (by-nc 3.0) which permits any noncommercial use, distribution, and reproduction in any medium, provided the original author(s) and source are credited.
We applied a behavioural approach, based on the theory of planned behaviour. In agriculture, this theory can be used to study individual farmer beliefs to understand the intention to adopt agricultural management practices.

Based on preliminary semi-structured interviews with 24 farmers, we have prepared and disseminated a structured questionnaire in dairy farms in the plain of northern Italy, in arable farms in the plain of northern, central, and southern Italy, and in arable farms in the hill of central and southern Italy. The questionnaire contained questions to reveal subjective beliefs of the farmers on the outcomes of incorporating crop residue, and on the referents and control factors that might influence adoption. We have received 315 filled questionnaires from 16 regions and 54 provinces.

The survey has identified major drivers and barriers towards the incorporation of crop residue in the soil. The main drivers were the expected improvement of soil quality (higher soil organic matter, improved structure and fertility), the expected increase of grain protein concentration in the following wheat crop, the availability of adequate machinery, the prohibition of burning crop residue, and the knowledge that incorporation is important (which emphasizes the importance of an effective advisory service). The main barriers were the costs of incorporation, the need to increase the use of nitrogen fertiliser when straw is incorporated, and the problems to sow the following crop in the presence of residue.

While on the basis of the preliminary interviews we expected that the possibility to sell the straw and the slow residue decomposition in the soil could be barriers against residue incorporation in the soil, questionnaire results did not confirm this expectation. The survey did not indicate that farmers are particularly worried about crop residue as potential sources of weeds, pests and diseases.

Even if the methodology applied did not identify any of the referents as important barriers or drivers, there were important differences with respect to the perceived opinion of the social environment between adopters and non-adopters. This emphasizes the importance of an encouraging social environment for the propagation of good practices.

\section{Introduction}

Soils are a key component of ecosystems. Soils provide a habitat to plant roots, store water and nutrient and supply them to plants, recycle raw materials, and host a wide array of living organisms. Soil's life is fuelled by the addition of organic materials, like crop residue. Crop residue is the plant material remaining in the field after harvest of the useful product. Crop residue includes stems, leaves and parts of plant's reproductive structure that are not harvested, for example maize (Zea 
mays L.) cob. Farmers may decide to leave the residue in the field and, under conventional tillage, to plough it in the soil. Incorporation of crop residue in the soil has a number of demonstrated benefits: it increases soil organic matter content (Lehtinen et al., 2014), crop yield, and soil aggregate stability (Spiegel et al., 2014), and enhances soil life (Perucci et al., 1997). Conversely, other authors report that crop residue coverage decreased yield due to poor weed control, excessively wet and cold soils, and poor seed placement and stand (Swan et al., 1994). Wilhelm et al. (2004) reported contrasting effects of repeated straw incorporation on crop nitrogen $(\mathrm{N})$ uptake at harvest and maize yield. Despite the advantages of residue incorporation on the sustainability of the soil, some farmers may decide to burn or sell it. Quantitative information is lacking about the rate of adoption and reasons for adopting this practice in Italy.

The objective of the present work was to quantify the adoption of crop residue incorporation by Italian farmers, and to identify the barriers and drivers that they perceive towards the incorporation of crop residue in the soil.

One way to understand a farmers' reasoning behind adoption of agricultural management practices is to adopt a behavioural approach, referring to studies that employ actor-oriented quantitative methodologies for the investigation of decision making (Burton, 2004; EdwardsJones, 2006). This approach has been proven successful for performing attitudinal research and allows identifying the nature of the barriers in adopting agricultural management practices (Wauters et al., 2010; Wauters and Mathijs, 2013).

\section{Theoretical framework}

In this study we applied a behavioural approach, based on the theory of planned behaviour, according to which individual beliefs about a behaviour or practice are believed to determine intention and behaviour (Ajzen, 1988; Ajzen, 1991). The probability that an individual will actually perform behaviour increases with his/her intention to behave. The intention of a farmer to implement a certain management practice is determined by the degree to which implementing the practice is evaluated positively or negatively by the farmer (attitude), the feeling of social pressure from others (called referents) to perform or not perform a certain practice (subjective norm) and the subjective beliefs about the ease or difficulty of successfully performing the practice (perceived behavioural control) (Figure 1). According to the theory of planned behaviour, attitude is formed by the belief that the behaviour will be associated with a set of outcomes (behavioural belief strength), weighted by an evaluation of these outcomes (outcome evaluation). Subjective norm is thought to be a function of how much we perceive others (called referents) think we should perform the behaviour (normative belief), weighted by our motivation to comply with these referents. Finally, perceptions of behavioural control are determined by the belief that a set of control factors facilitate or obstruct the behaviour (control strength), weighted by the expected impact that these factors would have if they were to be present (control power). All these underlying subjective beliefs influence a farmers' intention to adopt a certain practice, and are acting as cognitive drivers or barriers, which encourage or discourage the farmer to adopt a specific practice.

\section{Materials and methods}

\section{Farm type zones}

To address the large variability of Italian farming and cropping systems, we identified three farm type zones (FTZs); this study was conducted in each of these FTZs. These farm type zones are combinations of agri-environmental zones (based on soil and climate data: Metzger et al., 2005) with farm specialisation data (Hijbeek et al., 2013). Farm type zones represent combinations of farm type and biophysical setting. Among the Italian FTZs, we have selected the most important ones in terms of area covered: IT1 (dairy farms in the plain of northern Italy), IT2 (arable farms without relevant livestock, in the plain of northern, central, and southern Italy), and IT3 (arable farms without relevant livestock, in the hill of central and southern Italy). As a consequence of this choice, crop residue in this research was mainly intended as maize stalks and winter cereal straw. The issue of residue incorporation is important in arable farms located on soils with low organic matter content. Fantappiè et al. (2010) have indicated that current estimates of soil organic carbon (C) concentrations are significantly lower than those of about 30 years ago, particularly in soils under arable crops.

\section{General strategy}

We applied a sequential mixed method, by combining qualitative and quantitative research techniques at different stages in time (Creswell and Clark, 2011). In this study, the major quantitative data collection was preceded by a preparative qualitative step. First, preliminary semistructured interviews were conducted to identify all behavioural outcomes, normative referents and control factors for incorporation of crop residue. However, to assess whether these outcomes, referents and control factors confirm the opinion of a larger population of farmers, a large-scale survey was set up as a second step of the mixed method. After this major quantitative data collection, focus groups with farmers and other stakeholders were organised as a final qualitative step.

\section{Preliminary semi-structured interviews}

Twenty-four preliminary semi-structured interviews $(7,8$, and 9 in IT1, IT2 and IT3, respectively) were conducted during November 2012 March 2013. Each preliminary semi-structured interview lasted about $45 \mathrm{~min}$. To identify all behavioural outcomes, normative referents and control factors for incorporation of crop residue the interviewee could think of, we have put questions like: What are the advantages and disadvantages of incorporating crop residues in the soil? (for outcomes), Who might influence you when deciding whether or not to incorporate crop residue in the soil (for referents), and What factors or circumstances might favour/not favour the incorporation of crop residue in the soil? (for control factors). During these interviews, we did not influence the farmer by saying what outcomes, referents and control factors could be interesting in our mind, but registered only farmers' opinions.

\section{Analysis of preliminary semi-structured interviews and preparation of the questionnaire}

After the interview, we listed all the answers received, and grouped those that were mentioned by more than one farmer. We collected 8,8 , and 16 outcomes (respectively in IT1, IT2, and IT3); 2, 5, and 9 referents; and 8, 10, and 14 control factors. From this large set of answers, we made a selection for inclusion in the questionnaire to be sent to farmers, by incorporating outcomes, referents and control factors that were mentioned by more than one farmer. In a few cases, we included answers mentioned only once in one FTZ, if these were mentioned more than once in another FTZ. The final questionnaires contained 5 , 8 , and 7 outcomes (respectively in IT1, IT2, and IT3); 2,3 , and 3 referents; and 3, 3 , and 7 control factors.

For each outcome, each referent and each control factor included in the questionnaire, one question regarding belief and one question regarding weight were included. Regarding outcomes, we asked questions like Incorporating crop residue increases soil organic matter; 1: not 
likely, 5: very likely (behavioural belief strength of the outcome increased soil organic matter) and What do you think about increased soil organic matter? 1: not desirable; 5: very desirable (outcome evaluation of the outcome increased soil organic matter). For referents, we asked questions like Other farmers think I should (or should not) incorporate crop residue; 1: should not; 5: should (normative belief for the referent other farmers) and I take into consideration the opinion of other farmers; 1: not at all; 5: completely (motivation to comply for the referent other farmers). For control factors, we asked questions like 0 n my farm, I have to deal with adverse environmental conditions; 1: no; 5 : yes (control strength for the control factor adverse environmental conditions) and If I have to deal with adverse environmental conditions, it is very difficult (or very easy) to incorporate crop residue: 1: very difficult; 5: very easy (control power for the control factor adverse environmental conditions).

Besides these questions to reveal subjective beliefs of the farmers on these outcomes, referents and control factors, we asked the farmer whether crop residues are incorporated on the farm and on all or part of farm area (adoption question), and we included three questions regarding the intention to incorporate the residue during the next year. The three questions expressed the same concept with a different wording (I will incorporate crop residue next year, I will adopt crop residue incorporation next year, and Next year I have the intention to practice crop residue incorporation) and were randomised within the questionnaire. These replicated questions were used to estimate the internal consistency of the answers received. Internal consistency of the scale was measured by Cronbach's $\alpha$ (Cronbach, 1951; cut-off value of 0.7 ).

Finally, some questions on general farm characteristics were included: localisation, age of the farmer, farm size, area devoted to different crops, number of livestock, tillage methods used, soil texture, and soil slope of farm parcels.

During June 2013 the draft questionnaire was tested with a small number of farmers, to check clarity and time for compilation. For dissemination of the questionnaire to farmers, we were dependent on the support of many persons throughout Italy, ranging from advisors of professional organisations, producer associations, to advisors attached to the RICA network. These persons have sent the questionnaire to farmers, and took care of sending the answers back to us. The questionnaires were returned during the summer and autumn 2013.

\section{Data analysis}

Using the answer to the questions Do you incorporate crop residues on at least a portion of the farm area?, we distinguished adopters (who answered yes) from non-adopters (who answered no). We then calculated the mean of each answer separately for adopters and nonadopters. These means were analysed by assuming that answers in the central range (2.5-3.5) of the interval can be classified as neutral, while answers outside this interval are not. We then decided that an outcome, referent or control factor: i) is a driver for adopters and nonadopters if the mean answer on both questions related to each outcome, referent and control factor was not in the range 2.5-3.5 for both groups of farmers (for example, mean behavioural belief strength $=3.8$ and mean outcome evaluation $=4.3$ ); ii) is a driver only for adopters if the mean answer on both questions related to each outcome, referent and control factor was not in the range 2.5-3.5 for adopters, and at least one of the two paired answers was in the range 2.5-3.5 for nonadopters; iii) is a barrier for adopters and non-adopters if the mean answer on both questions related to each outcome, referent and control factor was not in the range 2.5-3.5 for both groups; iv) is a barrier only for non-adopters if the mean answer on both questions related to each outcome, referent and control factor was not in the range 2.5-3.5 for non-adopters, and at least one of the two paired answers was in the range 2.5-3.5 for adopters.

For each farmer and each outcome, referent and control factor, we finally calculated the combined effects (as indicated in schema of Figure 1) of the two-paired answers using these equations:

attitude $=$ behavioural belief strength $\times($ outcome evaluation -3$)$

subjective norm $=($ normative belief -3$) \times$ motivation to comply

perceived behavioural control $=$ control strength $\times($ control power -3$)(3)$

These combined effects can range from -10 to +10 .

The results of this analysis are reported in Table 1, which contains the combined effects; asterisks are used to indicate drivers and barriers.

\section{Results and discussion}

We received a total of 315 questionnaires from 16 regions and 54 provinces. Respondents were mostly men of 30-60 years. In about half of the farms, the farm size was smaller than 50 ha. The major crops were maize and common/durum wheat (Triticum aestivum L. and Triticum durum Desf.). Most of the farms adopted traditional tillage, while no-tillage was adopted only by a minority. Irrigation was practiced regularly in IT1. A percentage of sixty-nine, $93 \%$ and $69 \%$ of the respondents incorporated crop residue on at least a portion of farm area, respectively in IT1, IT2, and IT3. We obtained Cronbach's $\alpha$ of 0.97 , 0.92 , and 0.96 in IT1, IT2, and IT3, respectively, indicating excellent internal consistency. The average answer to the three intention questions was $3.32,4.42$, and 3.64 in IT1, IT2, and IT3, respectively (given on 1-5 scale, with $1=\mathrm{No}$, and $5=\mathrm{Yes}$ ).

All cognitive drivers and barriers resulting from this study were assigned to categories (Table 1). The categories soil and environment, financial, cultivation technique and social had a similar number of drivers and barriers $(6,9,7$, and 7, respectively), while legislation contained only one driver. The category social included five referents and two control factors. Cultivation technique and soil and environment contained mostly outcomes, while financial contained both outcomes and control factors.

\section{Soil quality}

Farmers are well aware of the positive effects of crop residue incorporation on soil sustainability: with the application of this practice, they consider an improvement of soil structure, an increase of soil organic matter, and of soil fertility more in general very likely. Moreover, they believe these advantages can be translated into increased crop yields and reduced use of mineral fertilisers. This is indicated (Figures 2 and 3 ) by high behavioural belief strengths. These

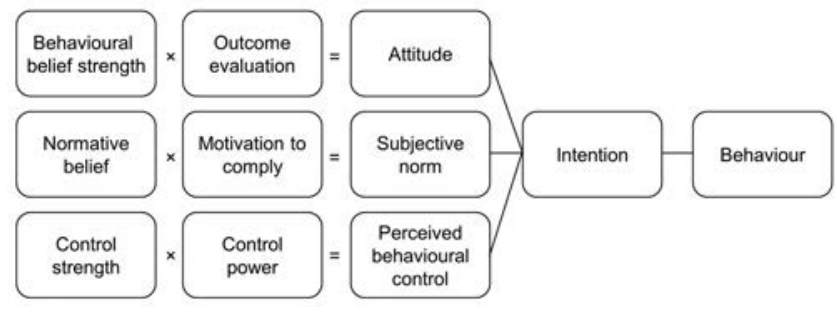

Figure 1. Theory of planned behaviour (adapted from Ajzen, 1991). 
results are similar to the observations in four European countries (Bijttebier et al., 2014). Considering that these outcomes are highly desirable (as indicated by their high outcome evaluations), they can be considered as important drivers towards the incorporation of crop residue in the soil (Table 1). Indeed, their attitude was rather high. This belief of farmers is well supported by scientific literature, reporting that crop residues may act as a source of nutrients or as a source of stable organic matter which improves soil physical, chemical, biological and hydraulic characteristics (Blanco-Canqui and Lal, 2009; Powlson et al., 2011). Zavattaro et al. (2012) reported that maize produced more total biomass when crop residues (stalks, cobs, and bracts) were returned to the soil.

Behavioural belief strengths of soil-related benefits of crop residue incorporation are high for both adopters and non-adopters. This suggests that, while operating in rather heterogeneous conditions, adopters and non-adopters expect their cropping systems to behave similarly regarding the effects of crop residues. One possible conclusion is that adopters are not concentrated in one part of the FTZ (with non-adopters occupying the remaining part).

Improved soil fertility might lead to an increase of grain wheat protein concentration. This was identified as a driver for adopters in IT2.

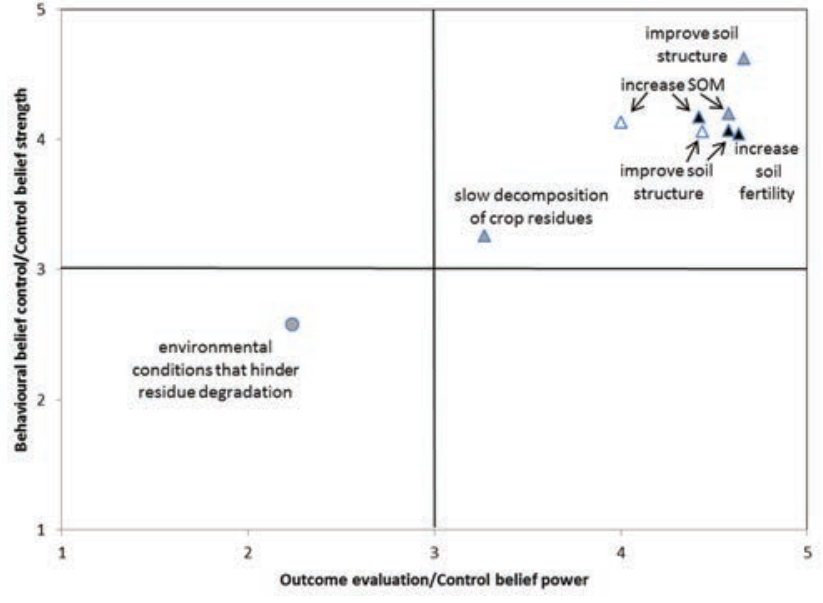

Figure 2. Outcomes and control factors related to soil and environment. Positioning of the outcome is based on the mean values for outcome evaluation and behavioural belief strength (triangles). Positioning of the control factor is based on the mean values for control strength and control power (circles). White symbol=IT1; grey symbol=IT2; black symbol=IT3.

Table 1. Mean values for attitudes, normative beliefs, and perceived behavioural controls of outcomes, referents, and control factors towards the incorporation of crop residue in the soil, as surveyed among Italian farmers in 2014.

\begin{tabular}{|c|c|c|c|c|c|}
\hline Farm type zones & Type of answer & er or barrier & IT1 & IT2 & IT3 \\
\hline $\begin{array}{l}\text { Soil and environment } \\
\text { Increase soil fertility } \\
\text { Improve soil structure } \\
\text { Increase soil organic matter } \\
\text { Adverse environmental conditions that hinder residue degradation } \\
\text { Slow decomposition of crop residues in soil }\end{array}$ & $\begin{array}{l}\text { Outcome } \\
\text { Outcome } \\
\text { Outcome } \\
\text { Control factor } \\
\text { Outcome }\end{array}$ & $\begin{array}{l}\text { Driver } \\
\text { Driver } \\
\text { Driver }\end{array}$ & $\begin{array}{l}6.20^{*} \\
4.61^{*}\end{array}$ & $\begin{array}{c}7.17^{* *} \\
6.76^{*} \\
-2.31 \\
0.48\end{array}$ & $\begin{array}{l}6.73^{*} \\
6.42^{*} \\
6.19^{*}\end{array}$ \\
\hline $\begin{array}{l}\text { Financial } \\
\text { Increase straw requirement at farm scale } \\
\text { Incorporation costs (residue chopping and distribution) } \\
\text { High price of crop residue } \\
\text { Loss of income if residues are not sold } \\
\text { Possibility of selling crop residue } \\
\text { Increase crop yield } \\
\text { Access to market of winter cereal straw } \\
\text { Gain through crop residues sale } \\
\text { Possibility of giving crop residue for free }\end{array}$ & $\begin{array}{l}\text { Outcome } \\
\text { Control factor } \\
\text { Control factor } \\
\text { Outcome } \\
\text { Control factor } \\
\text { Outcome } \\
\text { Control factor } \\
\text { Outcome } \\
\text { Control factor }\end{array}$ & $\begin{array}{l}\text { Barrier } \\
\text { Barrier } \\
\text { Barrier }\end{array}$ & $-4.21^{* *}$ & $-1.99 * *$ & $\begin{array}{c}-2.51^{* *} \\
-1.75^{*} \\
-3.92 \\
-1.86\end{array}$ \\
\hline $\begin{array}{l}\text { Cultivation technique } \\
\text { Adequate machinery available } \\
\text { Increase grain wheat protein concentration } \\
\text { Reduce the use of mineral fertilisers } \\
\text { Reduce weeds and fungi in the following crop } \\
\text { Increase the use of nitrogen fertiliser } \\
\text { Hinder the sowing of following crop (due to crop residue) } \\
\text { Increase weeds, pests and diseases } \\
\text { Increase risk of fungal diseases }\end{array}$ & $\begin{array}{l}\text { Control factor } \\
\text { Outcome } \\
\text { Outcome } \\
\text { Outcome } \\
\text { Outcome } \\
\text { Outcome } \\
\text { Outcome } \\
\text { Outcome }\end{array}$ & $\begin{array}{l}\text { Driver } \\
\text { Driver }\end{array}$ & 2.56 & $\begin{array}{c}2.31^{* *} \\
5.07 \\
-2.28^{* *} \\
-4.41\end{array}$ & $\begin{array}{c}-3.92 * * \\
-3.92 * * \\
-3.81\end{array}$ \\
\hline $\begin{array}{l}\text { Legislation } \\
\quad \text { Prohibition of burning crop residue }\end{array}$ & Control factor & Driver & & $4.74 * *$ & $4.16^{* *}$ \\
\hline $\begin{array}{l}\text { Social } \\
\text { Knowledge (incorporation is important) } \\
\text { Lack of knowledge of advantages of incorporation } \\
\text { Advisors of companies selling production factors } \\
\text { Advisors of producer associations } \\
\text { Other farmers } \\
\text { Family members } \\
\text { Companies that collect crop residues } \\
\end{array}$ & $\begin{array}{c}\text { Control factor } \\
\text { Control factor } \\
\text { Referent } \\
\text { Referent } \\
\text { Referent } \\
\text { Referent } \\
\text { Referent } \\
\end{array}$ & Driver & $\begin{array}{c}-0.03 \\
2.07\end{array}$ & $\begin{array}{r}2.96 \\
2.41 \\
-0.44 \\
\end{array}$ & $\begin{array}{l}2.32 \\
1.27 \\
1.54\end{array}$ \\
\hline
\end{tabular}

T1, dairy farms in the plain of northern Italy; IT2, arable farms without relevant livestock, in the plain of northern, central, and southern Italy; IT3, arable farms without relevant livestock, in the hill of central and southern Italy. *Driver or barrier for both adopters and non-adopters; **Driver only for adopters; barrier only for non-adopters. 


\section{Residue decomposition in the soil}

During preliminary semi-structured interviews, arable farmers complained that, particularly in areas with clay soils and low rainfall, crop residues do not decompose rapidly in the soil. For several of them this appeared to be a very serious constraint to the incorporation of residue in the soil. Some authors, such as Børresen (1999) and Silgram and Chambers (2002), observed $\mathrm{N}$ immobilisation during the decay of the straw. We have therefore included questions in IT2 about the slow decomposition of residues (an outcome) and about the environmental conditions that slow down decomposition (a control factor). The answers received did not allow us to classify them as barriers: the outcome of a slow decomposition received a mean of about 3 for both the behavioural belief strength and the outcome evaluation, indicating that this was not considered a very likely event and that, even if it would occur, it was not perceived as a very good or a very bad thing (Figure 2 ). The environmental conditions that slow down residue decompositions were not perceived as particularly strong (mean control strength of about 2.5); however, if present, their effect was perceived to make crop residue incorporation more difficult (mean control power of about 2 ). This situation explains other findings of the study. First of all, some farmers in IT3, mainly non-adopters, indicated to prefer giving the straw of winter cereals for free rather than incorporating it in the soils of their farm (Figure 3). This might mean that non-adopters have more possibilities compared to adopters to give the residue for free (mean control strength of 3.79), and that in their opinion this hampers them from incorporating crop residue in the soil (mean control power of 2.79). Another issue connected to the decomposition of residue in the soil is the expected increase of nitrogen fertiliser use (Figure 4): it is well known that, to favour residue decomposition, inorganic $\mathrm{N}$ shall be applied when incorporating residue, due to the high $\mathrm{C} / \mathrm{N}$ ratio of residue biomass. The farmers in IT2 and IT3 are aware of this, which is of course not desirable; we considered it as a barrier for nonadopters in IT2 and IT3.

To circumvent the problem of slow residue decomposition, in some Italian regions farmers used to burn crop residue. Despite the loss of organic matter and risk of fires, this is seen as a convenient way to dispose of the residue biomass and to avoid risks of pests and diseases. The legislation now forbids this practice in most areas. We have verified (Figure 5) that in IT2 and IT3 restrictive legislation is a driver towards residue incorporation in the soil (Figure 5). Finally, crop residue might also hinder the sowing of the following crop (Figure 4): this barrier was verified in IT3.

\section{Weeds, pests and diseases}

During the preliminary semi-structured interviews, farmers have expressed concerns that the incorporation of residue in the soil (opposed to removing them from the field) could increase the number of weeds, or the pressure of fungi and pests. Scientific experiments confirm that some crop diseases and pests can be enhanced when straw is either left on the surface or only incorporated to shallow depth just before sowing. Blandino et al. (2012) reported that residue incorporation decreased fungi attacks in wheat, when compared to nonincorporation (interaction with tillage). Maiorano et al. (2008) showed that residues lying on the surface of the soil played a major role on Fusarium spp. infection and on the subsequent deoxynivalenol contamination; similar results were obtained by Dill-Macky and Jones (2000). Our results (Figure 4) indicate that these outcomes were not drivers or barriers due to mean behavioural belief strength of about 3 , indicating that farmers did not believe that these drawbacks were particularly likely.

\section{Financial issues}

The role of market was not unequivocally described by the questionnaire results (Figure 3). After the preliminary semi-structured interviews, we expected that the possibility to sell the straw would be a barrier against residue incorporation in the soil. This issue was tested with different questions in IT1, IT2, and IT3. The answers received did not allow us to confirm our expectation. The access to market of winter cereals straw was not a barrier in IT1 because, while farmers believed that have access to this market (high control strength), they did not perceive this condition as discouraging towards crop residue incorpo-

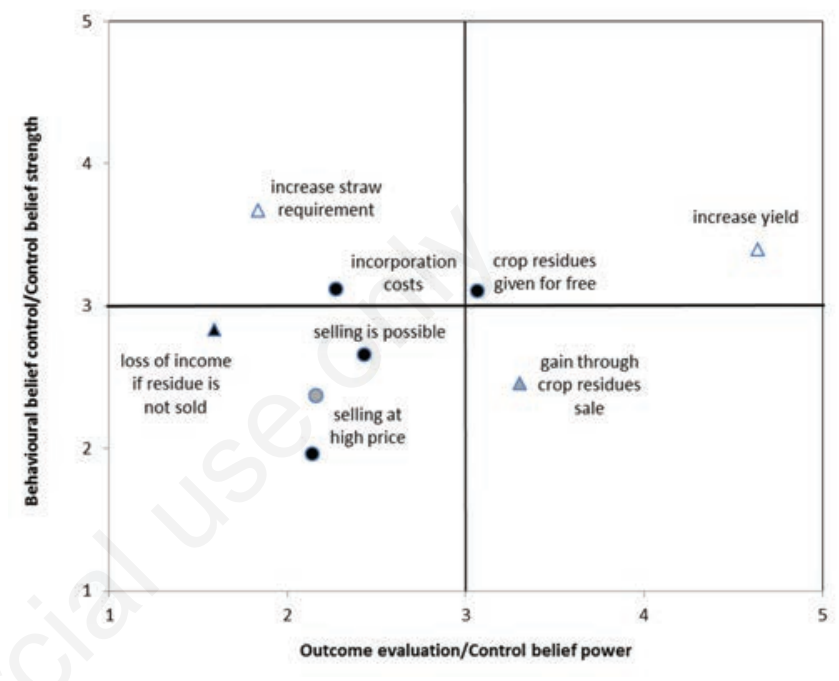

Figure 3. Outcomes and control factors related to financial issues. Positioning of the outcome is based on the mean values for outcome evaluation and behavioural belief strength (triangles). Positioning of the control factor is based on the mean values for control strength and control power (circles). White symbol=IT1; grey symbol=IT2; black symbol=IT3.

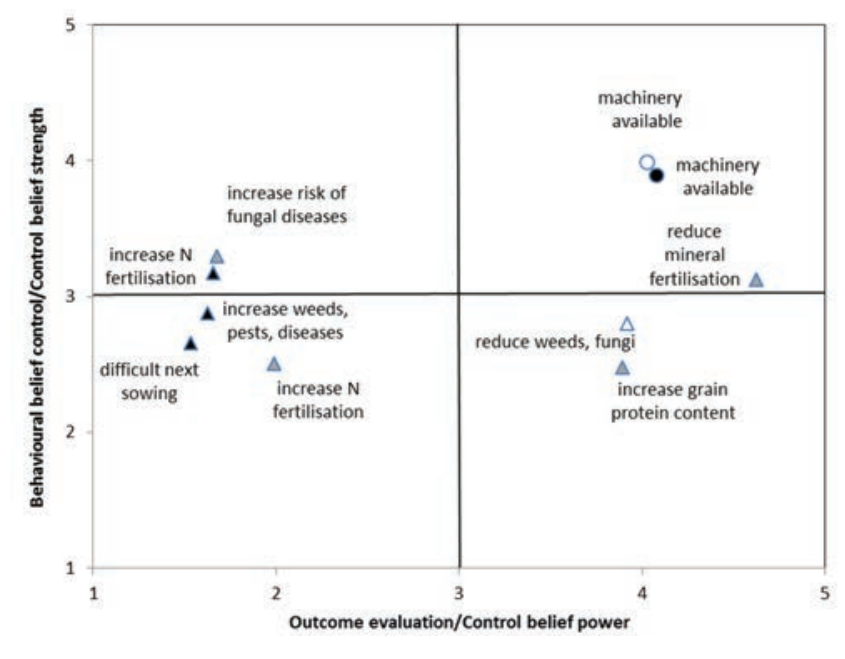

Figure 4. Outcomes and control factors related to cultivation technique. Positioning of the outcome is based on the mean values for outcome evaluation and behavioural belief strength (triangles). Positioning of the control factor is based on the mean values for control strength and control power (circles). White symbol=IT1; grey symbol=IT2; black symbol=IT3. 
ration (mean control power of about 3 ). We realised only after completing the survey that, while we intended that the access to straw market was aimed at access to market for selling residues, this could have been interpreted by some respondents as access to the market for buying straw.

Earning money through crop residue selling was not a barrier to residue incorporation in IT2. Although it would be desirable to obtain an additional income by selling crop residues (high outcome evaluation), the probability of this event was not considered as very likely (low behavioural belief strength). In addition, in IT2 farmers have clearly indicated that the residue price is not high (the control factor high price of crop residue received a low mean control strength). Similar results were obtained in IT3, where the loss of income as a result of not selling the residues was not considered very likely. Consistent with this indication, farmers in IT3 have also indicated that it is not easy to sell crop residues (mean control strength of about 2 for the factors possibility of selling crop residue and high price of crop residue). In IT2 and IT3 the high price of crop residue was identified as a barrier to incorporation only for non-adopters.

In IT1 the most obvious disadvantage of crop residue incorporation was the increase of straw requirement at farm scale (mean behavioural belief strength of 3.7): in a dairy farm, if the straw produced in the field is incorporated in the soil (and therefore cannot be used as litter), other straw has to be bought on the market, which is not desirable (mean outcome evaluation of 1.9). Therefore, this outcome was a barrier in IT1, but only for non-adopters. A t-test to compare adopters and non-adopters identified a significant difference $(\mathrm{P}<0.05)$ between the two groups for the behavioural belief strength of the increase of straw requirements, which was considered less likely by adopters. This might be linked to different animal housing systems in the two groups of farmers (with the adopters requiring less or no straw in the stable).

Finally, in IT3 we have also surveyed the importance of costs of residue incorporation. The answers indicated that incorporation costs were a barrier for non-adopters only.

In between financial and cultivation technique is the availability of adequate machinery (Figure 4). This control factor was tested in IT1 and IT3. In both FTZs, adopters think that adequate machinery is available on the farm to manage crop residue and that it was a factor favouring residue incorporation; therefore we classified it as a driver for adopters. This result was in partial contrast with the findings emerged from the semi-structured interviews, when several farmers from the South of Italy complained about the lack of straw-chopping tools on combine harvesters used in their area.

\section{Social issues}

In IT1 and IT2 we have included questions about the role of knowledge (Figure 5). The knowledge on the advantages of the incorporation (Table 1) was a driver in IT3 for adopters, and the lack of knowledge was not a barrier in IT1.

Among the referents, none of the referents (other farmers, advisors of companies selling production factors, companies that collect crop residues, advisors of producers associations, family members: Figure 5) could be classified as a driver or a barrier (Table 1). It is worth noting that a t-test conducted to compare adopters and non-adopters indicated that the normative belief was significantly different between the two groups $(\mathrm{P}<0.001)$, while the motivation to comply was not. This occurred for all referents, with only two exceptions: companies that collect crop residues in IT2, and advisors of producers associations in IT3. This means that adopters are surrounded by referents whom they believe to be more in favour of residue incorporation compared to nonadopters, while the two groups trust the referents to the same extent. In other words, it is not a matter of how much value the farmer adds to the opinion of his referents, but a matter of what a farmer thinks his referents think he/she should do. In IT2, companies that collect crop residues (e.g., connected to the paper industry) did not appear as being strongly in favour or against residue incorporation (median normative belief of 3). This was somewhat unexpected, because during preliminary semi-structured interviews several farmers had insisted on the interest towards straw collection by subjects external to the farm. In IT3, the advisors of producer associations are positive towards the incorporation of crop residues (high mean normative belief), but farmers do not give sufficient weight to their opinions (as seen by the motivation to comply). Family members are less insisting on the adoption, and therefore have a lower subjective norm compared to the other referents.

\section{Conclusions}

This survey has demonstrated that farmers are well aware of the advantages of crop residue incorporation on the improvement of soil fertility and the increase of crop yield. These outcomes, together with the prohibition of crop residue burning, were the most important drivers identified in this work. Being aware of the advantages of crop residue incorporation was identified as a driver both by the quantitative methodology applied, and by the interviews. This finding emphasizes the need of an effective advisory service.

Regarding the role of market, we did not reach any conclusive result. While it would seem logical that the demand of cereal straw would discourage residue incorporation, the results show that this was not true for the farmers interviewed. In some cases, traditions have an important impact on a farmers' decision whether or not to sell or incorporate residue, with only a weak relation to market conditions (high or low residue selling price).

From the social point of view, even if the methodology applied did not identify any of the referents as an important barrier or driver, we have measured important differences with respect to the perceived opinion

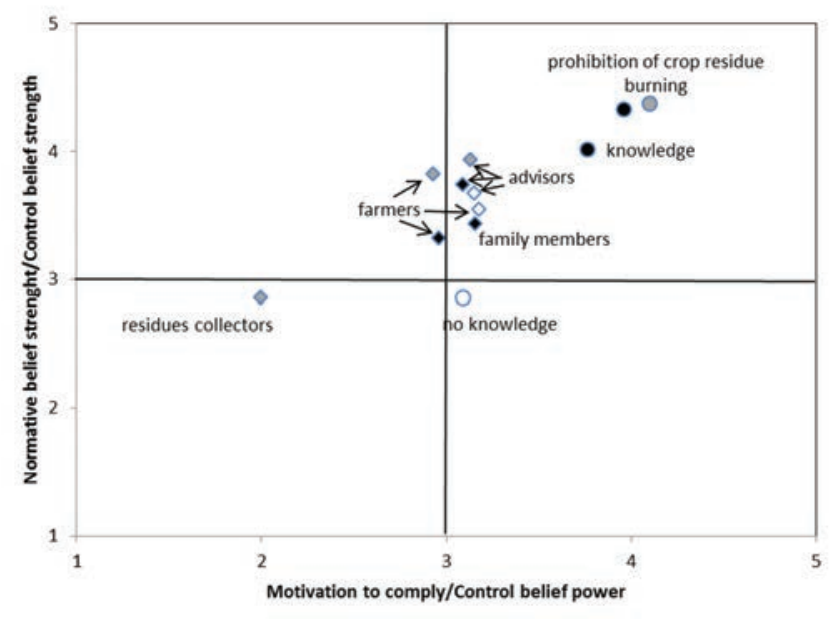

Figure 5. Legislation, referents and socially-related control factors. Positioning of the referent is based on the mean values for normative belief and motivation to comply (diamonds). Positioning of the control factor is based on the mean values for control strength and control power (circles). White symbol=IT1; grey symbol=IT2; black symbol=IT3. 
of the social environment between adopters and non-adopters of the practice, a fact which emphasizes the importance of an encouraging social environment for the propagation of ideas and of good practices.

The survey did not indicate that farmers are particularly worried about crop residue as potential sources of weeds, pests and diseases.

We conclude that farmers need clearer and conclusive information about the conditions favouring straw degradation in soil, the seedbed preparation problems in the presence of crop residues, and the effects of crop residue incorporation on weeds, pests and fungi (not only under conventional tillage, but also with minimum- and no-tillage).

\section{References}

Ajzen I, 1988. Attitudes, personality and behaviour. Dorsey Press, Chicago, IL, USA.

Ajzen I, 1991. The theory of planned behavior. Organ. Behav. Hum. Dec. 50:179-211.

Bijttebier J, Ruysschaert G, Hijbeek R, Werner M, Raschke I, Pronk A, Schlatter N, Guzmán G, Syp A, Bechini L, Turpin N, Guiffant N, Zavattaro L, Costamagna C, 2014. Impacts of soil management on indicators for climate change mitigation. Wageningen, The Netherlands. FP7 CATCH-C project. Available from: http://www.catch-c.eu/deliverables/WP3\%20Task\%203\%203\% 20CC_D3.334_final.pdf

Blanco-Canqui H, Lal R, 2009. Crop residue management and soil carbon dynamics. pp 291-309 in Soil carbon sequestration and the greenhouse effect. 2nd ed. SSSA Special Publication 57. ASA-CSSASSSA, Madison, WI, USA. Available from: https://dl.sciencesocieties.org/publications/books/abstracts/sssaspecialpubl/soilcarbonseque/291

Blandino M, Haidukowski M, Pascale M, Plizzari L, Scudellari D, Reyneri A, 2012. Integrated strategies for the control of Fusarium head blight and deoxynivalenol contamination in winter wheat. Field Crops Res. 133:139-49.

Børresen T, 1999. The effect of straw management and reduced tillage on soil properties and crop yields of spring-sown cereals on two loam soils in Norway. Soil Till. Res. 51:91-102.

Burton RJF, 2004. Reconceptualising the "behavioural approach" in agricultural studies: a socio-psychological perspective. J. Rural Stud. 20:359-71.

Creswell JW, Clark VLP, 2011. Designing and conducting mixed methods research. 2nd ed. SAGE Publications, Los Angeles, CA, USA.

Cronbach LJ, 1951. Coefficient alpha and the internal structure of tests. Psychometrika 16:297-334.

Dill-Macky R, Jones RK, 2000. The effect of previous crop residues and tillage on Fusarium head blight of wheat. Plant Dis. 84:71-6.

Edwards-Jones G. 2006. Modelling farmer decision-making: concepts, progress and challenges. Anim. Sci. 82:783-90.

Fantappiè M, L'Abate G, Costantini EAC, 2010. Factors influencing soil organic carbon stock variations in italy during the last three decades. In: Zdruli P, Pagliai M, Kapur S, Faz Cano AF (Eds.), Land degradation and desertification: assessment, mitigation and remediation. Springer, Amsterdam, Netherlands, pp 435-465. Available from: http://www.springerlink.com/content/v2w317h67034g201/ abstract/

Hijbeek R, Wolf J, van Ittersum, Martin K, 2013. A typology of farming systems, related soil management and soil degradation in eight European countries. Wageningen, The Netherlands. Available from: http://www.catch-c.eu/deliverables/D2.242-A\%20typology \%20of\%20farming\%20systems.pdf

Lehtinen T, Schlatter N, Baumgarten A, Bechini L, Krüger J, Grignani C, Zavattaro L, Costamagna C, Spiegel H, 2014. Effect of crop residue incorporation on soil organic carbon and greenhouse gas emissions in European agricultural soils. Soil Use Manage. 30:524-38.

Maiorano A, Blandino M, Reyneri A, Vanara F, 2008. Effects of maize residues on the Fusarium spp. infection and deoxynivalenol (DON) contamination of wheat grain. Crop Prot. 27:182-8.

Metzger MJ, Bunce RGH, Jongman RHG, Mücher CA, Watkins JW, 2005. A climatic stratification of the environment of Europe. Global Ecol. Biogeogr. 14:549-63.

Perucci P, Bonciarelli U, Santilocchi R, Bianchi AA, 1997. Effect of rotation, nitrogen fertilization and management of crop residues on some chemical, microbiological and biochemical properties of soil. Biol. Fertil. Soils 24:311-6.

Powlson DS, Glendining MJ, Coleman K, Whitmore AP, 2011. Implications for soil properties of removing cereal straw: results from long-term studies. Agron. J. 103:279-87.

Silgram M, Chambers BJ, 2002. Effects of long-term straw management and fertilizer nitrogen additions on soil nitrogen supply and crop yields at two sites in eastern England. J. Agr. Sci. 139:115-27.

Spiegel H, Zavattaro L, Guzmán G, D’Hose T, Pecio A, Schlatter N, ten Berge HFM, Grignani C, Molendijk L, Ruysschaert G, Bechini L, Costamagna C, Haslmayr HP, Lehtinen T, Baumgarten A, Krüger J, Syp A, Fotyma M, Jarosz Z, Sáenz de Rodrigáñez M, Vanwalleghem T, Vanderlinden K, Laguna A, Giráldez JV, van den Berg W, Hoek H, Runia W, 2014. Impacts of soil management practices on crop productivity, on indicators for climate change mitigation, and on the chemical, physical and biological quality of soil. Wageningen, The Netherlands. FP7 CATCH-C project. Available from: http://www. catch-c.eu/deliverables/D3.371_0verall_report.pdf

Swan JB, Higgs RL, Bailey TB, Wollenhaupt NC, Paulson WH, Peterson $\mathrm{AE}, 1994$. Surface residue and in-row treatment effects on longterm no-tillage continuous corn. Agron. J. 86:711.

Wauters E, Bielders C, Poesen J, Govers G, Mathijs E, 2010. Adoption of soil conservation practices in Belgium: an examination of the theory of planned behaviour in the agri-environmental domain. Land Use Policy 27:86-94.

Wauters E, Mathijs E, 2013. An Investigation into the socio-psychological determinants of farmers' conservation decisions: method and implications for policy, extension and research. J. Agric. Educ. Ext.19:53-72.

Wilhelm WW, Johnson JMF, Hatfield JL, Voorhees WB, Linden DR, 2004. Crop and soil productivity response to corn residue removal: a literature review. Agron. J. 96:1-17.

Zavattaro L, Monaco S, Sacco D, Grignani C, 2012. Options to reduce N loss from maize in intensive cropping systems in Northern Italy. Agric. Ecosyst. Environ. 147:24-35. 